\title{
Epidermolysis bullosa simplex, generalized severe
}

INSERM

\section{Source}

INSERM. (1999). Orphanet: an online rare disease and orphan drug data base.

Epidermolysis bullosa simplex, generalized severe. ORPHA:79396

Epidermolysis bullosa simplex, Dowling-Meara type (EBS-DM) is a basal subtype of epidermolysis bullosa simplex (EBS, see this term) characterized by the presence of generalized vesicles and small blisters in grouped or arcuate configuration. 